\title{
The Prevalence of Sexual Dysfunction among Patients with End Stage Renal Disease in Jamaica
}

\author{
KK Hoe ${ }^{1}$, AK Soyibo ${ }^{1,2}$, K James ${ }^{3}$, EN Barton ${ }^{1,2}$
}

\begin{abstract}
Background: Sexual performance and gratification impact quality of life. Although recognized in the literature as a problem, sexual dysfunction among patients with end stage renal disease (ESRD) has never been studied in Jamaica.

Subjects and Method: The prevalence of sexual dysfunction was determined among 268 adult Jamaican patients (166 males, 102 females) with ESRD who had been on haemodialysis for at least three months. Erectile dysfunction (ED) was assessed using the International Index of Erectile Function (IIEF). Female sexual dysfunction (FSD) was determined using the Diagnostic and Statistical Manual of Mental Disorders, fourth edition (DSM-IV) and International Classification of Diseases (ICD)-10 classifications of sexual disorders. Prevalence, severity of sexual dysfunctions and relationships with the primary aetiology of ESRD and anaemia were assessed.

Results: Erectile dysfunction, desire disorder and orgasmic disorder were found in 91.4\%, 88.3\%, and $81.6 \%$ of male subjects, respectively. The majority of male patients were dissatisfied with their performance at intercourse after progressing to ESRD. Hypoactive sexual disorder, sexual arousal and orgasmic disorders, and aversion sexual disorder were prevalent, found in $96 \%, 88.1 \%$ and $87.1 \%$ of female patients. All diabetic patients with ESRD reported hypoactive sexual disorder and orgasmic dysfunction; arousal disorder was found in 94.7\%. Aversion sexual disorder was found more among patients with underlying chronic glomerulonephritis. All patients with severe anaemia were found to have hypoactive sexual disorder and among these, $87.5 \%$ and $97.8 \%$ had severe arousal and orgasmic disorders, respectively.

Conclusion: Sexual dysfunction among patients with ESRD in Jamaica was prevalent in males and females. Associations exist between sexual dysfunction and diabetes mellitus, chronic glomerulonephritis and anaemia.
\end{abstract}

Keywords: Anaemia, erectile dysfunction, end stage renal disease, hypoactive sexual disorder, orgasmic disorder, sexual desire disorder, sexual dysfunction

\section{Prevalencia de la Disfunción Sexual entre los Pacientes con Enfermedad Renal en Etapa Terminal en Jamaica}

\author{
KK Hoe ${ }^{1}$, AK Soyibo ${ }^{1,2}$, K James ${ }^{3}$, EN Barton ${ }^{1,2}$
}

\begin{abstract}
RESUMEN
Antecedentes: El funcionamiento y la satisfacción sexual afectan la calidad de vida. Aunque la literatura la reconoce como un problema, la disfunción sexual entre los pacientes con enfermedad renal en etapa terminal (ERET) nunca se ha estudiado en Jamaica.

Sujetos y métodos: Se determinó la prevalencia de la disfunción sexual entre 268 pacientes jamaicanos adultos (166 varones y 102 hembras) con ERET, que habian estado en hemodiálisis por al menos tres meses. La disfunción eréctil (DE) fue evaluada mediante el índice internacional de función eréctil (IIFE). La disfunción sexual femenina (DSF) se determinó usando el Manual diagnóstico y estadístico de trastornos mentales, cuarta edición (DSM-IV) y las clasificaciones de trastornos sexuales en la
\end{abstract}

From: ${ }^{1}$ Department of Medicine, ${ }^{2}$ Caribbean Institute of Nephrology, Department of Medicine and ${ }^{3}$ Department of Community Health and Psychiatry, Faculty of Medical Sciences, The University of the West Indies, Kingston 7, Jamaica.
Correspondence: Dr AK Soyibo, Department of Medicine, Faculty of Medical Sciences, The University of the West Indies, Kingston 7, Jamaica. E-mail: adedamola.soyibo@uwimona.edu.jm,demoskey@hotmail.com 
Clasificación internacional de enfermedades (CIE)-10. Se evaluaron la prevalencia, la gravedad de las disfunciones sexuales y las relaciones con la principal etiología de ERET y la anemia.

Resultados: Se halló disfunción eréctil, trastorno de deseo, y trastorno orgásmico en 91.4\%, 88.3\% y $81.6 \%$ de los sujetos masculinos, respectivamente. La mayoría de los pacientes masculinos estaban insatisfechos con su desempeño en las relaciones sexuales después del avance de ERET. Trastornos sexuales hipoactivo, trastornos de la excitación sexual y del orgasmo, así como trastornos de aversión se caracterizaron por su prevalencia, y fueron hallados en $96 \%, 88.1 \%$ y $87.1 \%$ de los pacientes femeninos, respectivamente. Todos los pacientes diabéticos con ERET reportaron trastorno sexual hipoactivo y disfunción orgásmica. Se hallaron trastornos de excitación en el $94.7 \%$. El trastorno de aversión sexual se observó más entre los pacientes con glomerulonefritis crónica subyacente. Se halló que todos los pacientes con anemia presentaban trastorno sexual hipoactivo y entre éstos, $87.5 \%$ y 97.8\% presentaban trastornos severos de excitación y orgasmo, respectivamente.

Conclusión: La disfunción sexual entre los pacientes con ERET en Jamaica fue prevalente tanto en los varones como en las hembras. Existen asociaciones entre la disfunción sexual y la diabetes mellitus, la glomerulonefritis crónica y la anemia.

Palabras claves: Anemia, disfunción eréctil, enfermedad renal en etapa terminal, trastorno sexual hipoactivo, trastorno del deseo sexual, disfunción sexual

West Indian Med J 2013; 62 (9): 826

\section{INTRODUCTION}

The prevalence of erectile dysfunction (ED) among patients with chronic kidney disease (CKD) was first studied in the 1970s. Initial reports published by Abram et al (1975) as cited by Cerqueira et al (1) showed that the prevalence of ED reached levels of around $80 \%$. Varying degrees of ED have been described in end-stage renal disease (ESRD) patients by Neto and colleagues who found moderate ED in 35.4\% and minimal ED in $24.6 \%$ among 118 patients with ESRD; complete ED was reported by $25.4 \%$ of subjects (2). In one early (1985) study of dialysis patients, $79 \%$ of men complained of sexual dysfunction and $61 \%$ of erectile impotence following uraemia and the onset of regular dialysis therapy (3). In another study, a decade later, approximately $50 \%$ of uraemic men complained of ED, while an even greater percentage of both men and women complained of decreased libido and a marked decline in the frequency of intercourse (4). The latter study was consistent with earlier findings that 40 to $50 \%$ of patients with uraemia complained of erectile dysfunction and reported a significant decrease in frequency of intercourse (5). Kidneys perform vital functions for the body and kidney disease can affect several organ systems of the body in many different ways (6). Many studies have been done on problems related to ESRD including management of anaemia (79), nutrition (10-12), dialysis and calcium and phosphate metabolism $(13,14)$. However, one of the commonest associated symptoms of ESRD has been relatively neglected, that is, sexual dysfunction.

Sexual stimulation of the human male results in a series of psychological, neuronal, vascular and local genital changes. At least three different classifications for these changes have been described. Kolodny et al described a psychosexual response cycle that consists of four phases: excitement, plateau, orgasm and resolution (15).
Higher serum testosterone appears to be associated with greater sexual activity in healthy older but not younger men. Furthermore, higher testosterone levels may also shorten the latency of erection stimulated by exposure to erotic material (16). Testosterone replacement in hypogonadal males restores sexual interest, shortens latency and increases frequency and magnitude of nocturnal penile tumescence (17).

Erection is under the control of several neurological and vascular cascades (18). The ejaculation phase is controlled by sympathetic innervation of the genital organs and occurs as a result of a spinal cord reflex arc. Both physiological and psychogenic elements contribute to the genesis of the orgasmic phase. Local penile $\alpha$-adrenergic receptor activation is the most important neuromediator effecting detumescence (19).

Female sexual dysfunction is characterized by disturbances in the processes of the sexual response cycle or by pain associated with sexual intercourse. The female sexual response cycle can be divided into the phases: desire, excitement, orgasm and resolution (20).

The aetiology of sexual dysfunction in patients with ESRD is multi-factorial and among the most probable causes are autonomic neuropathy, diminished concentration of testosterone, hyperprolactinaemia, vascular disease of the penile arteries and veins, medications and psychogenic factors (21).

The American Psychiatric Association's Diagnostic and Statistical Manual of Mental Disorders, $4^{\text {th }}$ edition (DSM-IV; 1994), as well as the World Health Organization's International Statistical Classification of Diseases and Related Health Problems-10 (ICD-10), published in 1992, contain a classification system for female sexual disorders that is based on the Masters and Johnson and Kaplan linear 
model of the female sexual response (22-24). Female sexual disorders are classified as:

- Sexual desire disorders (SDD) which are subdivided into hypoactive sexual desire (HSD) disorder and sexual aversion disorder

- Sexual arousal disorder

- Orgasmic disorder (OD)

- Sexual pain disorder which includes dyspareunia, vaginismus and non-coital sexual pain disorder

The purpose of this study was to assess the prevalence, severity of sexual dysfunction and relationships with the primary aetiology of ESRD and anaemia.

\section{SUBJECTS AND METHODS}

A cross-sectional study was done among 268 Jamaican patients (166 males, 102 females) with ESRD. Subjects were recruited from 10 of 15 sites providing dialysis in Jamaica in the public and private sectors during the time of the study. One site was geographically distant and logistically prohibitive to engage and was thus excluded. Four private dialysis centres declines to participate in the study. Data were collected using an interviewer-administered questionnaire. The questionnaire elicited information regarding sociodemographic characteristics, primary aetiology of ESRD, frequency and satisfaction with sexual activity/ performance, and sexual function/dysfunction. The study was carried out from August 2011 to July 2012 and all patients attending for dialysis during that period were recruited for the study, having met eligibility criteria. Subjects had to be over 18 years of age and had to have been on chronic haemodialysis for at least three months. Erectile dysfunction was assessed using the International Index of Erectile Function (IIEF). The assessment of female sexual dysfunction (FSD) was determined based on the DSM-IV and ICD-10 classifications of sexual disorders. The prevalence and severity of sexual dysfunctions and the relationship with the primary aetiology of ESRD were assessed using Chisquared tests. The association between anaemia and sexual dysfunction was also ascertained.

\section{RESULTS}

The mean age of participants in this study was $49.78 \pm 13.78$ (range 18-80) years for the males and $44.58 \pm 12.44$ (range 18-65) years for the females. The prevalence of sexual dysfunction among the ESRD patients in Jamaica was high in both genders. Almost all males (97.5\%) reported intercourse dissatisfaction. Erectile dysfunction was the most prevalent sexual dysfunction among the males $(91.4 \%)$ followed by sexual desire disorder $(88.3 \%)$ and orgasmic disorder $(81.6 \%)$.

Diabetes mellitus (DM) was the strongest associated co-morbidity for all kinds of male sexual dysfunctions. Erectile dysfunction was found in $97.5 \%$ of diabetic patients, $95.8 \%$ reported decreased sexual desire and $89.6 \%$ reported orgasmic dysfunction $(p=0.007)$. Hypertension $(\mathrm{HTN})$ has already been recognized as the commonest cause of ESRD in Jamaica $(25,26)$ and in this study, $46.9 \%$ of males suffered from hypertension. However, hypertensive male patients less commonly reported sexual dysfunctions $(\mathrm{ED}=89.3 \%$, $\mathrm{SDD}=88.2 \%, \mathrm{OD}=78.9 \%$ ) than their diabetic counterparts.

Diabetic patients were more likely to suffer severe forms of sexual desire disorder and orgasmic disorder compared to those with other co-morbidities. Patients who had chronic glomerulonephritis (GN) had a greater tendency to develop severe erectile dysfunction. Additionally, male patients with haemoglobin level more than $10 \mathrm{~g} / \mathrm{dL}$ suffered less severe orgasmic dysfunction and desire dysfunction $(p=$ 0.0001 and $p=0.025$, respectively) than those with haemoglobin level $9.99 \mathrm{~g} / \mathrm{dL}$ or less.

Among the participants in this study, the proportion of married males and females were $58.4 \%$ and $41.5 \%$, respectively. The majority of male and female patients with ESRD $(60.8 \%$ each) were found to be sexually inactive within the last month. Among married persons, statistically similar proportions of male patients $(56.4 \%)$ and female patients $(51.4 \%)$ reported that they had been sexually inactive for more than a month $\left(\chi^{2}=2.89, \mathrm{df}=1, p=0.089\right)$. By the aetiology of ESRD, there were statistically significant differences in the prevalence of orgasmic dysfunction, being highest among the male diabetic population (89.6\%) compared to those with hypertension $(78.9 \%)$, chronic glomerulonephritis $(50 \%)$ and other causes $(84.6 \%)$ of ESRD $\left[\chi^{2}=\right.$ $12.21, \mathrm{df}=3, p=0.007]$. Diabetic patients also most commonly reported severe orgasmic dysfunction (DM: 67.4\%, HTN: $61.7 \%$, GN: $62.5 \%$ and other: $62.4 \%$ ).

Similar to the orgasmic disorder, male sexual desire dysfunction was found most commonly among diabetic patients $(95.8 \%)$ followed by hypertensive patients $(88.2 \%)$. This disorder was less frequent in male patients whose primary aetiology of ESRD was with other (76.9\%) and chronic glomerulonephritis $(68.8 \%)$. The difference in proportions was statistically significant $\left(\chi^{2}=10.27, \mathrm{df}=3, p=0.016\right)$ [Table 1].

A total of 102 female patients with ESRD participated in the study. The relationship between the prevalence of

Table 1: Characteristics by the primary aetiology in males with end stage renal disease $[\%,(n)]$

\begin{tabular}{lcccc}
\hline & HTN & DM & CGN & Other \\
\hline Male & $(\mathrm{n}=78)$ & $(\mathrm{n}=48)$ & $(\mathrm{n}=15)$ & $(\mathrm{n}=25)$ \\
Mean age (years) & $48.76 \pm 1.51$ & $59.27 \pm 1.48$ & $36 \pm 2.69$ & $43.69 \pm 2.2$ \\
Prevalence of ED & $89.3(67)$ & $97.9(47)$ & $86.7(13)$ & $88.0(22)$ \\
Severe ED & $65.7(44)$ & $66.0(31)$ & $69.2(9)$ & $59.1(13)$ \\
Prevalence of SDD & $88.2(67)$ & $95.8(46)$ & $68.8(11)$ & $76.9(20)$ \\
Severe SDD & $22.4(15)$ & $43.5(20)$ & $9.1(1)$ & $15.0(3)$ \\
Prevalence of OD & $78.9(60)$ & $89.6(43)$ & $50.0(8)$ & $84.6(22)$ \\
Severe OD & $61.7(37)$ & $67.4(29)$ & $62.5(5)$ & $62.4(12)$ \\
\hline
\end{tabular}

$\mathrm{HTN}=$ Hypertension, DM = Diabetes, $\mathrm{CGN}=$ Chronic glomerulonephritis, ED $=$ Erectile dysfunction, $\mathrm{SDD}=$ Sexual desire disorder, $\mathrm{OD}=$ Orgasmic disorder 
different female sexual dysfunctions and the primary aetiology of ESRD was examined. All diabetic female patients, $95.6 \%$ of female hypertensives and $95.2 \%$ of female patients with chronic glomerulonephritis reported hypoactive sexual disorder. Severe hypoactive sexual disorder was noted in $52.6 \%, 46.5 \%$ and $45 \%$ of female patients with diabetes, hypertension and chronic glomerulonephritis, respectively, as their primary cause of ESRD.

The prevalence of aversion sexual disorder was highest in those patients who had chronic glomerulonephritis as the primary aetiology of ESRD (90.5\%). Corresponding figures were $86.7 \%$ and $84.2 \%$, respectively, for females with hypertension and diabetes as primary aetiological factors. Severe aversion sexual disorder was most commonly found among females with chronic glomerulonephritis (57.9\%) compared to females with diabetes (56.3\%) and hypertension (53.8\%). Arousal disorder was reported more by chronic glomerulonephritis patients (95.2\%) compared to diabetics (94.7\%) and hypertensive $(84.4 \%)$ patients. However, among females, severe arousal disorder was found most among those with diabetes $(72.2 \%)$, followed by those with hypertension $(60.5 \%)$ and glomerulonephritis $(60 \%)$ as the primary cause of ESRD.

Among females with diabetes as the primary cause of ESRD, $94.7 \%$ had female orgasmic dysfunction and $66.7 \%$ of them were found to have severe orgasmic dysfunction. Among females with hypertension as the primary cause of ESRD, the prevalence of orgasmic dysfunction was $91.1 \%$ and $65.9 \%$ of them suffered severe orgasmic dysfunction [Table 2].
All male patients with severe anaemia were found to have intercourse dissatisfaction. Those patients with mild anaemia suffered less severe orgasmic dysfunction $\left(\chi^{2}=\right.$ $17.44, \mathrm{df}=2, p<0.0001)$ as well as less desire dysfunction $\left(\chi^{2}=7.36, \mathrm{df}=2, p=0.025\right)$ than those with moderate or severe anaemia. It was also noted that higher haemoglobin levels were associated with less severe erectile dysfunction.

With respect to anaemia as a possible risk factor for sexual dysfunction, the study showed a high prevalence $(100 \%)$ of hypoactive sexual disorder among the severely anaemic females. This disorder was found to be $95.3 \%$ prevalent in females with moderate anaemia and $94.1 \%$ in females with mild anaemia $(n=102)$. With regards to other female sexual dysfunctions, aversion sexual disorder was found in $100 \%$ of patients with mild anaemia and $90 \%$ in severely anaemic patients. This may indicate that the degree of anaemia has no obvious impact on aversion sexual disorder among female patients with ESRD.

Arousal sexual disorder and orgasmic disorder were found more among females with severe anaemia [haemoglobin $<7 \mathrm{~g} / \mathrm{dL}], 87.5 \%$ and $97.8 \%$, respectively. These disorders were less commonly seen in those female patients with mild anaemia $(76.5 \%)$ but these differences were not statistically significant.

\section{DISCUSSION}

Erectile dysfunction is more frequent among end-stage renal failure patients than the normal population. Patients with ESRD experience a significant decrease in quality of life, due

Table 2: Characteristics by primary aetiology in females with end stage renal disease [\%, (n)]

\begin{tabular}{lcccc}
\hline & HTN & DM & CGN & Other \\
\hline Female & $(\mathrm{n}=45)$ & $(\mathrm{n}=19)$ & $(\mathrm{n}=21)$ & $(\mathrm{n}=17)$ \\
Mean age (years) & $48.36 \pm 1.51$ & $50.58 \pm 2.48$ & $32.52 \pm 2.03$ & $42.76 \pm 3.22$ \\
Prevalence of HSD & $95.6(43)$ & $100(19)$ & $95.2(20)$ & $88.2(15)$ \\
Severe HSD & $46.5(20)$ & $52.6(10)$ & $45.0(9)$ & $33.3(5)$ \\
Prevalence of aversion SD & $86.7(39)$ & $84.2(16)$ & $90.5(19)$ & $82.4(14)$ \\
Severe aversion SD & $53.8(21)$ & $56.3(9)$ & $57.9(11)$ & $50.0(7)$ \\
Prevalence of arousal SD & $84.4(38)$ & $94.7(18)$ & $95.2(20)$ & $76.5(13)$ \\
Severe arousal SD & $60.5(23)$ & $72.2(13)$ & $60.0(12)$ & $84.6(11)$ \\
Prevalence of OD & $91.1(41)$ & $94.7(18)$ & $85.7(18)$ & $70.6(12)$ \\
Severe OD & $65.9(27)$ & $66.7(12)$ & $72.2(13)$ & $91.7(11)$ \\
\hline
\end{tabular}

$\mathrm{HTN}=$ Hypertension, $\mathrm{DM}=$ Diabetes, $\mathrm{CGN}=$ Chronic glomerulonephritis, $\mathrm{ED}=$ Erectile dysfunction, $\mathrm{SDD}=$ Sexual desire disorder, $\mathrm{OD}=$ Orgasmic disorder, HSD $=$ Hypoactive sexual disorder, $\mathrm{SD}=$ Sexual disorder

The mean haemoglobin level of male patients was 8.62 $\pm 2.39 \mathrm{~g} / \mathrm{dL}$ (range 3.76-13.1 g/dL). Female patients had mean haemoglobin of $8.24 \pm 1.96 \mathrm{~g} / \mathrm{dL}$ (range 4.1-12.0 $\mathrm{g} / \mathrm{dL}$ ). When categorized by anaemia into three groups according to haemoglobin levels (severe $\leq 7$, moderate 7.01$9.9 \mathrm{~g} / \mathrm{dL}$, mild $\geq 10 \mathrm{~g} / \mathrm{dL}-\leq 13.4 \mathrm{~g} / \mathrm{dL}$ ), most patients were found to have moderate anaemia ( $42.2 \%$ of males and $62.7 \%$ of females). both to the limitations imposed by the disease as well as the demands of the treatment that they receive.

The present study showed associations between diabetes mellitus, hypertension and all types of male sexual dysfunctions. Diabetes appears to be a major factor in sexual dysfunction among male ESRD patients. However, the potential contribution of chronic glomerulonephritis and other causes of ESRD cannot be ignored. All ESRD patients 
are at risk of developing sexual dysfunction regardless of cause of the ESRD. Male patients with severe anaemia appear to be at higher risk for orgasmic disorder and severe sexual desire problem than their counterparts with mild anaemia. Prevention of severe anaemia may reduce the occurrence of orgasmic and desire dysfunctions in males.

Among females, there may have been insufficient power to detect significant differences as a result of the smaller number of female subjects. According to the data available, female ESRD patients with diabetes are very likely to have hypoactive sexual disorder. This subgroup tended to have more severe female sexual dysfunctions than other groups with other co-morbidities/aetiologies of ESRD. Aversion sexual disorder was associated with chronic glomerulonephritis. Severe anaemia was found to be associated with female hypoactive sexual disorder. Correction of severe anaemia could probably improve severe arousal disorder and orgasmic disorder for female patients with ESRD as these disorders were notably found more in patients with severe anaemia.

The associations between individual antihypertensive medications and sexual dysfunctions were not analysed. Antihypertensive drugs were used by $77.8 \%$ of all participants. Mediator or interaction effects of such medications on sexual dysfunction in the population studied are unknown. This is an area for future research.

High prevalence of sexual dysfunctions among patients with ESRD regardless of gender mandates that physicians raise the issue during the clinical interview of such patients. Appropriate counselling for such patients and their partners should be conducted to improve understanding of these common ESRD-associated disorders. Therapeutic trial with sildenafil should be considered in those patients with erectile dysfunction if there are no absolute contraindications and correctable clinical issues have been addressed. The satisfaction rate on the overall efficacy questions in response to $25 \mathrm{mg}$ of oral sildenafil were $80 \%$ in a haemodialysis group and $82 \%$ in a peritoneal dialysis group (27). Correction of severe anaemia has well-established benefits. In the ESRD patient, this might include alleviation of severe sexual desire and orgasmic dysfunction.

This is the first report on the prevalence of sexual dysfunction among patients with ESRD in the Caribbean. Use of standard international instruments in this study allowed comparability with worldwide results. The smaller sample size of the female group might have reduced the ability to detect associations.

\section{CONCLUSION}

This study demonstrates the very high prevalence of sexual dysfunctions among patients with ESRD in Jamaica. A significant proportion has reduced regular sexual activity as a consequence of the disease. End stage renal disease should be considered as a risk factor for sexual dysfunction. Sexual dysfunctions are more likely to be found in ESRD patients with diabetes and hypertension. Erectile dysfunction is the commonest sexual dysfunction for male and hypoactive sexual disorder is the commonest among female ESRD patients.

In ESRD patients, severe anaemia is a putative risk factor for erectile dysfunction and female hypoactive sexual disorder. The prevention/correction of severe anaemia may reduce severe orgasmic dysfunction for both males and females.

\section{REFERENCES}

1. Cerqueira J, Moraes M, Glina S. Erectile dysfunction: prevalence and associated variables in patients with chronic renal failure. Int $\mathrm{J}$ Impot Res 2002; 14: 65-71.

2. Neto AF, de Freitas Rodrigues MA, Saraiva Fittipaldi JA, Moreira ED Jr. The epidemiology of erectile dysfunction and its correlates in men with chronic renal failure on hemodialysis in Londrina, southern Brazil. Int J Impot Res 2002; 14 (Suppl 2): S19-26.

3. Rodger RS, Fletcher K, Dewar JH, Genner D, McHugh M, Wilkinson R et al. Prevalence and pathogenesis of impotence in one hundred uremic men. Uremia Invest 1984-1985; 8: 89-96.

4. Steele TE, Wuerth D, Finkelstein S, Juergensen D, Juergensen P, Kliger AS et al. Sexual experience of the chronic peritoneal dialysis patient. J Am Soc Nephrol 1996; 7: 1165-8.

5. Procci WR, Goldstein DA, Aldestein J, Massry S-G. Sexual dysfunction in the male patient with uremia: a re-appraisal. Kidney Int 1981; 19: $317-23$.

6. Emedicinehealth.com. Chronic kidney disease causes, symptoms, diagnosis, and treatment [Internet]. WebMD, Inc; 2014 [updated 2014 Feb 14; cited 2014 Feb 14]. Available from: http://www.emedicine health.com/chronic_kidney_disease/article_em.htm\#chronic_kidney_di sease_overview

7. National Institute for Health Care Excellence. Anaemia management in people with chronic kidney disease: NICE clinical guideline 114. NICE; 2011 [cited 2014 Feb 14]. Available from: http://www.nice.org.uk/ nicemedia/live/13329/52853/52853.pdf

8. Lerma EV. Anemia of chronic disease and renal failure [Internet]. WebMD, Inc; 2014 [updated 2013 Oct 28; cited 2014 Feb 14]. Available from: http://emedicine.medscape.com/article/1389854-overview

9. National Kidney Foundation. KDOQI clinical practice guideline and clinical practice recommendations for anemia in chronic kidney disease: 2007 update of hemoglobin target. National Kidney Foundation; 2007 [cited 2014 Feb 14]. Available from: http://www. kidney.org/Professionals/kdoqi/guidelines_anemiaUP/index.htm

10. National Kidney Foundation, KDOQI. Nutritional management in children with chronic kidney disease. Stages 2 to 5 and 5D. New York: National Kidney Foundation; 2009 [cited 2014 Feb 14]. Available from https://www.kidney.org/professionals/tools/pdf/NutritionalMngmtCKD 2_5_5D.pdf

11. Beekley MD. Update on nutrition and chronic kidney disease [Internet]. WebMD, Inc; 2014 [updated 2007 Jul 25; cited 2014 Feb 14]. Available from: http://www.medscape.com/viewarticle/559159

12. Dewar D, Soyibo AK, Barton EN. Nutritional markers in patients undergoing chronic haemodialysis in Jamaica. West Indian Med J 2012; 61: 284-9.

13. National Kidney Foundation. NKF KDOQI Guidelines [Internet]. New York: National Kidney Foundation; 2002 [cited 2014 Feb 14]. Available from: https://www.kidney.org/professionals/kdoqi/guidelines_ckd/toc. htm

14. Frazer YT, Soyibo AK, McGrowder D, Barton EN. The importance of bone biomarkers in the diagnosis of renal osteodystrophy. West Indian Med J 2010; 59: 332-7.

15. Kolodny RC, Masters WH, Johnson VE. Sexual anatomy and physiology. In: Textbook of Sexual Medicine. Boston: Little Brown and Co; 1979. 
16. Lange JD, Brown WA, Wincze JP, Zwick W. Serum testosterone concentration and penile tumescence changes in men. Horm Behav 1980; 14: 267-70.

17. O'Carroll R, Shapiro C, Bancroft J. Androgens, behaviour and nocturnal erection in hypogonadal men: the effects of varying the replacement dose. Clin Endocrinol 1985; 23: 527-38.

18. Kinsey AC, Pomeroy WB, Martin CE. Early sexual growth and activity. In: Kinsey AC, Pomeroy WB, Martin CE. Sexual Behavior in the Human Male. Philadelphia: WB Saunders Co; 1948.

19. Kandeel FR, Koussa VKT, Swerdloff RS. Male sexual function and its disorders: physiology, pathophysiology, clinical investigation, and treatment. Endocr Rev 2001; 22: 342-88.

20. American Psychiatric Association. Diagnostic and Statistical Manual of Mental Disorders. $4^{\text {th }}$ ed, text revision. Washington, DC: American Psychiatric Press; 2000.

21. Carson CC, Patel MP. The epidemiology, anatomy, physiology, and treatment of erectile dysfunction in chronic renal failure patients. Adv Ren Replace Ther 1999; 6: 296-309.
22. American Psychiatric Association. Diagnostic and Statistical Manual for Mental Disorders. 4th ed. Washington, DC: American Psychiatric Press; 1994.

23. World Health Organization. ICD 10: International Statistical Classification of Diseases and Related Health Problems. Geneva: World Health Organization; 1992.

24. Basson R, Berman J, Burnett A, Derogatis L, Ferguson D, Fourcroy J et al. Report of the International Consensus Development Conference on female sexual dysfunction: definitions and classifications. J Urol 2000; 163: 888-93.

25. Soyibo AK, Barton EN. Chronic kidney disease in the Englishspeaking Caribbean. West Indian Med J 2009; 58: 596-600.

26. Soyibo AK, Barton EN. Report from the Caribbean Renal Registry, 2006. West Indian Med J 2007; 56: 51.

27. YenicerioGlu Y, Kefi A, Aslan G, Cavdar C, Esen AA, Camsari T et al. Efficacy and safety of sildenafil for treating erectile dysfunction in patients on dialysis. BJU Int 2002; 90: 442-5. 